\title{
Dynamics of a headwater system and peatland under current conditions and with climate change
}

\begin{tabular}{|r|l|}
\hline Journal: & Hydrological Processes \\
\hline Manuscript ID: & HYP-12-0676.R1 \\
\hline Watey - Manuscript type: & Research Article \\
\hline Complete List of Authors: & $\begin{array}{l}\text { Levison, Jana; Guelph University, School of Engineering } \\
\text { Larocque, Marie; University of Quebec at Montreal, Earth and atmospheric } \\
\text { Sciences } \\
\text { Véronique, Fournier; Université du Québec à Montréal, Sciences de la Terre } \\
\text { et de I'atmosphère } \\
\text { Gagné, Sylvain; Université du Québec à Montréal, Sciences de la Terre et } \\
\text { de l'atmosphère } \\
\text { Pellerin, Stéphanie; Université de Montréal, Biologie } \\
\text { Ouellet, Marie-Audray; Université du Québec à Montréal, Sciences de la } \\
\text { Terre et de l'atmosphère }\end{array}$ \\
\hline Keywords: & $\begin{array}{l}\text { Peatland, Headwater system, Climate change, Groundwater flow modeling, } \\
\text { Covey Hill (Quebec, Canada) }\end{array}$ \\
\hline
\end{tabular}



CONDITIONS AND WITH CLIMATE CHANGE

\section{J. Levison ${ }^{1,3}$, M. Larocque ${ }^{1 *}$, V. Fournier ${ }^{1}$, S. Gagné ${ }^{1}$, S. Pellerin ${ }^{2}$ and M.A. Ouellet ${ }^{1}$}

$13{ }^{1}$ Centre de recherche pour l'étude et la simulation du climat à l'échelle régionale, Département

14 des sciences de la Terre et de l'atmosphère - Université du Québec à Montréal, C.P. 8888, succ.

15 Centre-Ville, Montréal (QC), Canada ; tel : 514-987-3000 ext. 1515 ; fax : 514-987-7749;

16 larocque.marie@uqam.ca

$17{ }^{2}$ Institut de recherche en biologie végétale, Université de Montréal, Jardin botanique de

18 Montréal, 4101 rue Sherbrooke est, H1X 2B2, Montréal, Québec, Canada;

19 stephanie.pellerin.1@umontreal.ca

$20{ }^{3}$ Current address: School of Engineering, University of Guelph, Richards Building, N1G 2W1,

21 Guelph, Ontario, Canada, jlevison@uoguelph.ca,

$22 *$ Corresponding author 


\section{ABSTRACT}

26 Interactions between headwater aquifers and peatlands have received limited scientific attention.

27 Hydrological stresses, including those related to climate change, may adversely impact these

28 interactions. In this study, the dynamics of a southern Quebec headwater system where a peatland

29 is present is simulated under current conditions and with climate change. The model is calibrated

30 in steady-state on field-measured data and provides satisfactory results for transient state

31 conditions. Under current conditions, simulations confirm that the peatland is fed by the fractured

32 bedrock aquifer year round and provides continuous baseflow to its outlets. Climate change is

33 simulated through its impact on groundwater recharge. Predicted precipitation and temperature

34 data from a suite of Regional Climate Model scenarios provide a net precipitation variation range

35 from $+10 \%$ to $-30 \%$ for the $2041-2070$ horizon. Calibrated recharge is modified within this range

36 to perform a sensitivity analysis of the headwater model to recharge variations $(+10 \%,-15 \%$ and

$37-30 \%$ ). Total contribution from the aquifer to rivers and streams varies from $+14 \%$ to $-44 \%$ of the

38 baseline for $+10 \%$ to $-30 \%$ recharge changes from spring 2010 data, for example. With higher

39 recharge, the peatland receives more groundwater, which could significantly change its

40 vegetation pattern and eventually ecosystem functions. For $-30 \%$ recharge, the peatland becomes

41 perched above the aquifer during the summer, fall and winter. Recharge reductions also induce

42 sharp declines in groundwater levels and drying streams.

43

44 KEYWORDS

45 Peatland; headwater system; climate change; groundwater flow modeling; Covey Hill; southern

46 Quebec Canada 


\section{INTRODUCTION}

49 In Canada, peatlands cover up to $14 \%$ of the land area and comprise over $90 \%$ of present

50 wetlands (Waddington et al., 2009). They are the most prevalent wetland type in the southern part

51 of the province of Quebec (Ducks Unlimited Canada, 2006). Peatlands play an important

52 ecological role in maintaining fragile habitats (e.g. Calmé et al., 2002). They contribute uniquely

53 to both physical and chemical hydrologic processes including streamflow, evapotranspiration and

54 water storage (Waddington et al., 2009). In eastern Canada, as in other parts of the world,

55 peatlands are under threat from human activities, particularly urban expansion and agriculture

56 (Poulin et al., 2004), and potentially climate change (Moore, 2002; Tarnocai, 2006). In general,

57 very little is known about peatland hydrological dynamics and linkages to local or regional

58 groundwater flow systems. This is especially true for headwater peatlands which can be

59 significant hydrological reservoirs in environments where bedrock hydraulic conductivity is low

60 and surrounding soils can be thin or nonexistent (Winter, 2000).

61

62 Numerical modeling of groundwater flow through the peat and in the adjacent aquifer can be used

63 to better understand peatland-aquifer flow dynamics (Ackerman et al., 2009; Baird et al., 2011).

64 In regional scale groundwater flow models, surface water features such as lakes and peatlands are

65 typically represented using constant heads. This boundary condition overly constrains

66 groundwater flow around the peatland and prevents any consideration of temporal variations of

67 peatland-aquifer exchanges. For some peatland-specific studies, modeling simplifications such as

68 two-dimensional representations and steady-state flow regimes (Lapen et al., 2005) limit the

69 results about regional scale and seasonal hydrological processes. The modeling work of Reeve et

70 al. (2001) is a notable exception to the constant head peatland representation or peatland-specific

71 modeling simplifications. Using a regional groundwater flow model and an explicit representation

72 of flow processes between the peatlands and the aquifer, they showed that in the lowland Lake

73 Agassiz area, groundwater flow within the peatlands is driven by local flow systems. 
74 Nevertheless, the scientific literature holds few such examples of regional scale peatland-

75 groundwater interaction models. Simulating groundwater flow in fractured bedrock aquifers itself

76 is challenging because of the heterogeneous distribution of conductive fractures (Cook, 2003).

77 This can be further complicated by large vertical gradients present in fractured bedrock headwater

78 basins. Using an explicit representation of a peatland in a model to accurately simulate transient

79 fractured bedrock aquifer-peatland interactions in a complex headwater context has not, to our

80 knowledge, been previously investigated.

81

82 Climate change impacts on groundwater resources at a regional scale are increasingly studied

83 (e.g. Jyrkama and Sykes, 2007; Scibek et al., 2007). Results from these studies in different

84 locations show the possibility of increases and decreases in groundwater recharge, depending on

85 the topography, geology and climate, leading to a variety of trends in groundwater levels. It is

86 recognized that headwater streams in small catchments are more likely to be vulnerable to low-

87 flow impacts than larger river systems (Winter, 2007). In headwater catchments with shallow

88 bedrock aquifers, groundwater is probably also highly vulnerable to climate variations because of

89 slopes and limited (or no) surficial material overlying formations with low permeability which

90 leads to greater runoff and less infiltration (Kosugi et al., 2006). Investigations of climate change

91 effects on peatlands have focused on peat interactions with the atmosphere, notably carbon

92 exchanges (Strack et al., 2004; Belyea and Malmer, 2004), and on hydrologic processes occurring

93 within the organic deposits (e.g. Whittington and Price, 2006). Recently the impact of climate

94 change on wetland interaction with the surrounding aquifer has been studied (e.g. Ackerman et

95 al., 2009; Herrera-Pantoja et al., 2011), finding in particular a vulnerability with declining

96 groundwater levels. Changes in peatland-aquifer connectivity can impact stream and wetland

97 biogeochemistry (Devito, 1995; Brassard et al., 2000) which can induce vegetation changes (e.g.

98 Salinas et al., 2000) and lead to a flashier response to rainfall events (Greyson et al., 2010).

99 However, the amount of hydrological change a headwater system and its ecosystem can sustain 
100 before adverse impacts are observed is not well understood. In particular, the function of

101 peatlands in the hydrological and ecosystem resilience of headwater systems is mostly unknown.

102 This lack of knowledge limits the development and application of adaptation strategies such as

103 land and water resources management (e.g. protecting peatlands, reducing groundwater

104 withdrawal, and limiting deforestation and urban development) in headwater systems where

105 peatlands are present.

106

107 This research was initiated at the request of Nature Conservancy of Canada to better understand

108 the hydrological function of a headwater peatland recently identified for conservation. The goal

109 of this long term study is to determine if the peatland plays a role in maintaining groundwater

110 levels, as well as river baseflows, streams and springs which form habitats for endangered

111 salamander species (Larocque et al., 2006). Climate change was identified as the most eminent

112 threat to the low development Covey Hill area where the targeted headwater peatland is located.

113 This paper addresses these questions by using a numerical groundwater flow model to simulate

114 the dynamics of the headwater system under current conditions and with climate change-induced

115 recharge variations. Specifically, a groundwater flow model developed in MODFLOW

116 (Harbaugh, 2005) is used to simulate regional flows for the headwater system as well as local

117 aquifer-peatland interactions under current conditions and with a range of recharge scenarios

118 derived from Regional Climate Models.

\section{$120 \quad$ 2. Study area}

121 The Covey Hill peatland is located within the Covey Hill Natural Laboratory (Larocque et al., 122 2006), $74^{\circ} 00^{\prime} \mathrm{W}, 45^{\circ} 00^{\prime} \mathrm{N}$, near the Canada-USA border in the Chateauguay River watershed 123 (Figure 1). Covey Hill is the most northward extension of the Adirondack Mountains. The highest 124 point on the hill is located $345 \mathrm{~m}$ above sea level. Covey Hill comprises Cambrian sandstone of 125 the Potsdam Group (Covey Hill Formation), deformed and fractured during the Appalachian 
126 orogeny (Globensky, 1986). Groundwater flows in the fractured sandstone. This bedrock aquifer

127 is used by local residents for potable water supply.

128

129 The absence of surface deposits on large areas near the hilltop and south of the international

130 border shows the importance of erosion during the last ice advance (12 ky). In other areas, the hill

131 is covered by the thin, permeable and sandy Saint-Jacques till (Lasalle, 1981). Glaciolacustrine

132 sediments are found locally below $220 \mathrm{~m}$ above sea level (masl) (Parent and Occhietti, 1988).

133 Sandy beach deposits are located at the foot of the hill, between 80 and 100 masl (Tremblay et al.,

134 2010). Littoral sediments from the erosion of the rock substrate by the Champlain Sea and till are

135 abundant at the base of Covey Hill (see cross-section, Figure 1b). These sediments, composed of

136 highly permeable sands and gravels, are mostly located on the northern side of the hill. The

137 sandstone aquifer is generally unconfined over the study area. The till, silt and clay sediments in

138 the north are less permeable than the sandy deposits at the base of the hill. Groundwater flow

139 through the sandstone aquifer occurs in laterally-extensive sub-horizontal bedding planes,

140 connected by sub-vertical fractures and joints (Nastev et al., 2008). Covey Hill is considered an

141 important recharge area for the $2500 \mathrm{~km}^{2}$ Chateauguay aquifer (Croteau et al., 2010). Near the

142 end of the last glaciation, the breakout of paleo-lake Iroquois through an outlet near Covey Hill

143 created a relatively impervious sandstone pavement (also called Flat Rock) that extends from

144 below the peatland approximately $30 \mathrm{~km}$ southeastward into the Champlain Valley in the United

145 States (Franzi et al., 2002). The Blueberry and Gouffre lakes are remnants of this catastrophic

146 event and form deep reservoirs which store significant volumes of water along the Allen River

147 (Barrington et al., 1992).

148

149 The Covey Hill peatland is one of the few remaining undisturbed peatlands in southern Quebec

150 and one of the oldest known in the province. Basal peat ${ }^{14} \mathrm{C}$ dating shows that organic matter

151 started accumulating 13250 years B.P., probably soon after the breakout of paleo-lake Iroquois 
152 (Pellerin et al., 2007). The peatland covers an area of approximately $0.51 \mathrm{~km}^{2}$ near the hilltop.

153 The peat averages $1.4 \mathrm{~m}$ deep and reaches $3.2 \mathrm{~m}$ in some areas (Rosa et al., 2008; see Figure 1b).

154 To the west, the peatland feeds the Outardes River and to the east it discharges in the Allen River.

155 Fournier (2008) used hydraulic gradients and a water budget to demonstrate that groundwater

156 flows year round from the surrounding bedrock aquifer into the peatland. A vegetation study also

157 identified a minerotrophic transition zone (lagg) between the forests located on the bedrock and

158 the central peatland ombrotrophic sector (Pellerin et al. 2009). Surface water input to the

159 peatland from runoff has not been observed since the start of the peatland monitoring and is

160 considered negligible. Based on the piezometric map of Covey Hill the area contributing

161 groundwater to the peatland is estimated to be $1.7 \mathrm{~km}^{2}$.

162

\section{2. EXPERIMENTAL ANALYSIS}

\section{$164 \quad 2.1$ Available data}

165 Precipitation and temperature data are available from the Hemmingford weather station located

$16611 \mathrm{~km}$ from the peatland (Environment Canada, 2010). From 2007 to 2010, the annual average

167 precipitation was $1064 \mathrm{~mm}$ and the average annual temperature was $6.8^{\circ} \mathrm{C}$. Snow usually falls

168 between November and March. Potential evapotranspiration (PET) is calculated with the Oudin et

169 al. (2005) equation. This equation provides PET estimates based on mean daily air temperature

170 and on extraterrestrial radiation which is estimated following Morton (1983). The seasonal net

171 precipitation (precipitation - PET) is estimated for three-month periods between 2007 and 2010

172 (Table 1). It varies from a negative net precipitation in summer to a winter maximum of $285 \mathrm{~mm}$.

173 A negative net precipitation indicates seasons where potential evapotranspiration could not be

174 met by precipitation. Because of the sub-zero temperatures, the winter net precipitation

175 accumulates on the ground as snow and becomes available only during spring snowmelt. The

176 average annual PET calculated with the Oudin equation from 2007 to 2010 was $664 \mathrm{~mm} \mathrm{y}^{-1}$. The 
177 average net precipitation is therefore $400 \mathrm{~mm} \mathrm{y}^{-1}$ for this period and varies from 323 to $567 \mathrm{~mm} \mathrm{y}^{-}$ $178 \quad 1$.

179 Figure 1a shows the location of gauging stations and their contributing watersheds in the Covey 180 Hill Natural Laboratory where water levels have been recorded hourly since 2007 (Trutrack level 181 loggers) on the Allen River (29 $\mathrm{km}^{2}$ watershed) and the Outardes River ( $26 \mathrm{~km}^{2}$ watershed) as 182 well as on the Schulman stream $\left(2.7 \mathrm{~km}^{2}\right.$ watershed). For all gauging stations, rating curves were 183 constructed by measuring flow rates manually (Swoffer 2100 velocimeter). Flows were estimated

184 during the frost free period of May to October from 2007 to 2010 (2007 to 2009 for the Schulman 185 stream). The Chapman (1999) digital filter was used on the flow rate time series to separate 186 baseflows from total flows (see Table 1). Without field calibration it is difficult to determine the 187 baseflow recession constant $\mathrm{k}$, which describes the rate of baseflow decay. Here, a k value of 1880.99 was used to represent the relatively low groundwater contribution to river flows (cf. Gagné, 189 2010). Total flows and baseflows are similar for the Allen and Outardes rivers and are an order of 190 magnitude smaller for the Schulman stream, as expected when comparing watershed sizes (see

191 Figure 1). On average, the estimated baseflows represent 39, 27 and $29 \%$ of the total flows for the 192 Allen River, the Outardes River and the Schulman stream respectively. These proportions are 193 relatively small, but typical of values found in headwater streams (e.g. Croteau et al., 2010). The

194 proportionately larger baseflows on the Allen River can be explained by the presence of deep

195 lakes along its course that intercept significant volumes of groundwater and smooth the impact of 196 rain events.

198 Groundwater levels were measured in two bedrock piezometers located near the peatland (4.5 and

$19915 \mathrm{~m} \mathrm{depth}$ ), in nine private monitoring wells, and in three observation wells owned by the

200 Geological Survey of Canada (Solinst level loggers; hourly measurements year round). A total of

201371 heads are also available from a provincial water well database, the Système d'informations

202 hydrogéologiques (SIH) (Ministère du Développement durable, de l'Environnement, de la Faune 
203 et des Parcs-MDDEFP, 2010). Six piezometers (approximately $0.5 \mathrm{~m}$ depth) are located directly

204 in the peatland to monitor groundwater levels in the organic deposits (INW-PT2X level loggers;

205 hourly measurements during the frost free period of May to October). Several of these

206 piezometers and the shallow bedrock observation well are depicted in Figure 1b. The bedrock

207 water table is located near the surface (between 2 and $15 \mathrm{~m}$ depth). Groundwater flows generally

208 in a radial direction from the hilltop, in the laterally-extensive fractures and dissolution joints

209 rather than in the sandstone porosity (Nastev et al., 2008). Heads in the peatland are lower than in

210 the surrounding bedrock aquifer, indicating lateral groundwater input from the aquifer to the

211 peatland (Fournier, 2008).

212

213 Hydraulic conductivity $(\mathrm{K})$ values for the fractured bedrock are available from pumping tests and

214 packer tests reported in previous studies (Barrington et al., 1992; Lavigne et al., 2010a) and from

215 slug tests performed in the two bedrock observation wells located near the peatland (Fournier,

216 2008). Available data for bedrock $\mathrm{K}$ range from $4 \times 10^{-10}$ to $1 \times 10^{-4} \mathrm{~m} \mathrm{~s}^{-1}$. These highly variable

217 values correspond to a wide range of fracture apertures and connectivity, but clearly decrease

218 with depth. Peat hydraulic conductivity was estimated by Fournier (2008). For the top $0.3 \mathrm{~m}$, it

219 was estimated using an experimental tank reproducing Darcy's experiment (Rosa and Larocque,

2202008 ) and varies between 0.00189 and $0.00725 \mathrm{~m} \mathrm{~s}^{-1}$. Below this depth and down to $1 \mathrm{~m}$, it was

221 estimated with the Modified Cubic Method (Beckwith et al., 2003a) and varies between 2.1x10-8

222 and $1 \times 10^{-4} \mathrm{~m} \mathrm{~s}^{-1}$. Hydraulic conductivities show a significant decreasing pattern with depth.

223 Below $1 \mathrm{~m}, \mathrm{~K}$ is expected to be very low and probably significantly restricts flow in the lower

224 peat layers.

225

\subsection{Development of the groundwater flow model}

227 The MODFLOW software (Harbaugh, 2005) was used to simulate groundwater flow in the

228 fractured bedrock and interactions between the aquifer, the peatland and streams, assuming that 
229 the unconfined bedrock aquifer behaves as an equivalent porous medium. A digital elevation

230 model was built using elevation data from the Ministère des Ressources Naturelles (MRNF,

231 2007). The groundwater flow model is discretized in 16 layers for a total thickness of $96 \mathrm{~m}$ (layer

232 thickness increases from $0.25 \mathrm{~m}$ at the surface to $30 \mathrm{~m}$ at the base of the aquifer). The upper eight

233 layers are thin to allow an accurate representation of the peatland stratigraphy: the top two layers

234 (each $0.25 \mathrm{~m}$ thick) correspond roughly to the top portion of the acrotelm while the next layers

235 correspond to gradually more humified and less permeable peat layers (reaching the catotelm). A

236 variable head representation of the peatland was used rather than a constant head boundary

237 condition to ensure that simulated flows reflect the hydraulic properties of both the bedrock and

238 the organic deposits in changing hydrological conditions. This representation of the organic

239 deposits is nevertheless simplified and does not include lateral heterogeneity within the peat

240 deposits which can drive groundwater flow (Beckwith et al., 2003b).

241

242 The model extends north and east from Covey Hill into the St. Lawrence Lowlands and covers a

243 total area of $173 \mathrm{~km}^{2}$. It is limited to the northwest by the Outardes River and to the north by the

244 Noire River (Figure 2). A specified head boundary is used to allow groundwater flow to the

245 regional aquifer. A no-flow boundary is used approximately $9 \mathrm{~km}$ parallel to and east of the Allen

246 River. This is a flow line based on the piezometric map. The southern and southwestern limit is

247 set on the drainage basins of the Allen and Outardes rivers (i.e., a water-divide, thus a no-flow

248 boundary is used). The bedrock at the base of the model is a no-flow boundary. The model

249 consists of 9698 cells of $135 \mathrm{~m} \times 135 \mathrm{~m}$. Cells are refined over and around the peatland

$250(67.5 \mathrm{~m} \times 67.5 \mathrm{~m})$ to ensure a good representation of head variations. Figure 3 presents a three-

251 dimensional depiction of the model, with a vertical exaggeration of 10 times.

252

253 The Outardes and Allen rivers are represented using MODFLOW's River package in the top two

254 layers. The Blueberry Lake and the Gouffre Lake, as well as a marsh area in the USA portion of 
255 the Allen River are set as constant heads. Small permanent streams and tributaries are represented

256 using MODFLOW's Drain package in the top two layers. Recharge zones are determined

257 according to the slope and type of Quaternary deposits (Figure 2a, Table 2). The study area is

258 divided into four hydraulic conductivity zones (Figure 2b). Zone 1 corresponds to the peatland.

259 The Covey Hill formation is divided into three zones (2, 3 and 4) based on areas of similar

260 elevation and field hydraulic conductivity measurements (Lavigne et al., 2010a).

261

262 The model was calibrated in steady-state by manually adjusting the K values of the four hydraulic

263 conductivity zones using a trial and error procedure based on measured $\mathrm{K}$ data. Zonal recharge

264 and river and stream exchange coefficients were also calibrated. The storage coefficient for the

265 organic deposits (zone 1) was set to 0.7 , based on an estimation from water level increases

266 following precipitation events (Fournier, 2008) and was calibrated for the bedrock hydraulic

267 conductivity zones. The calibration targets are the available head measurements (SIH database,

268 bedrock observation wells, private monitoring wells and peatland piezometers) as well as the

269 baseflows estimated for the three gauging stations (Allen and Outardes rivers, Schulman stream).

270

271 In transient-state, the year is divided into four stress periods of 91 days (10 time steps in each

272 period) corresponding to spring, summer, fall and winter. Following a 20 year spin-up period, the

273 transient model was executed to simulate the 2007-2010 flows, the period during which detailed

274 transient hydrological data are available. In MODFLOW, multipliers are used to modify the value

275 of calibrated steady-state recharge for each transient period. These multipliers were calculated for

276 each 91 day season using the ratio of the net precipitation for the season of interest to the average

277 net precipitation for the calibrated steady-state period. This method assumes that seasonal

278 recharge is distributed analogously to the net precipitation ratios. That is, a lower net precipitation

279 will lead to a reduction in both runoff and infiltration. The same multipliers were used for all

280 recharge zones. In the model, the winter recharge is set to zero and transferred to the spring 
281 (when net precipitation is therefore usually the highest). For periods where the net precipitation is

282 a negative value (i.e. for some summer periods), the recharge in the model is also set to zero.

\section{$284 \quad 2.3$ Climate change scenarios}

285 The impact of climate change on groundwater recharge was investigated by considering net

286 precipitation values calculated with future time series of daily precipitation and temperature data.

287 It is assumed that recharge will follow the same pattern as net precipitation, such that a lower net

288 precipitation will lead to an analogous reduction in both runoff and infiltration. This might not

289 hold true if rainfall intensity increases or if there is less snow due to a shorter winter. Predicted

290 PET values were derived from Regional Climate Models (RCMs) future temperature time series

291 used in the Oudin et al. (2005) equation. Although using a daily weather generator and a recharge

292 model might provide more detailed input data for the groundwater flow model (cf. Herrera-

293 Pantoja et al., 2011), it would be much more labor intensive and is beyond the scope of this work.

295 The climate change scenarios are derived from four RCMs driven by six General Circulation

296 Models (GCMs). This form of dynamic downscaling provides a better representation of both

297 average conditions and extremes than other methods over the study area. Future RCM scenarios

298 were further downscaled using the daily translation bias correction method (Mpelasoka and

299 Chiew, 2009) to remove the biases between simulated and observed temperature and precipitation

300 variables.

301

302 Ten projections (Figure 4, Table 3) were selected from the 25 dynamically downscaled

303 simulations available for the Covey Hill area. Most of the simulations are outputs of the Canadian

304 Regional Climate Model (CRCM) (Music and Caya, 2007) and were generated and supplied by

305 the Ouranos Consortium on Regional Climatology and Adaptation to Climate Change. The

306 remaining simulations are from the North American Regional Climate Change Assessment 
307 Program. All projections are for the 2041-2070 climate. The 10 simulations account for $85 \%$ of

308 the future climate variability projected for the study site as established by a cluster analysis

309 carried out on the range of available RCM scenarios. The simulations are driven by six different

310 GCMs under the Intergovernmental Panel on Climate Change emissions scenarios A1B and A2

311 (IPCC, 2000). The A1B emissions scenario corresponds to a medium population growth, rapid

312 gross domestic product growth and a balance of all energy sources. The A2 scenario is based on

313 high population growth, medium gross domestic product growth, high energy use, medium-to-

314 high land-use changes, and slow introduction of more energy efficient technologies. The A2

315 scenario is one of the most commonly used scenarios (Jackson et al., 2011).

317 Future RCM scenarios predict annual average air temperatures increasing by $2.4^{\circ} \mathrm{C}$

318 (CRCM4.2.3_ECHAM\#1) to $3.6{ }^{\circ} \mathrm{C}$ (CRCM4.2.3_CGCM3\#2) for the 2041-2070 period. These

319 temperature increases far exceed the maximum difference of $1.6^{\circ} \mathrm{C}$ from the mean annual

320 temperature observed from 1971 to 2000 on Covey Hill. When used in the Oudin et al. (2005)

321 formula, the increased temperatures of the climate scenarios induce 15 to $21 \%$ increase in

322 predicted PET compared to the PET value of the reference period. Annual precipitation

323 projections range from a 3\% increase (CRCM_CCSM) to a 13\% increase (ECP2_GFDL). This

324 range of precipitation variation is small when compared to the $-19 \%$ to $+38 \%$ difference from the 325 mean precipitation observed from year to year during the reference period.

327 Stemming from these changes in temperature and precipitation, net precipitation varies from a

$32830 \%$ decrease (CRCM_CCSM) to a 10\% increase (CRCM4.2.3_ECHAM\#1). The net

329 precipitation scenarios do not all agree about the sign of change: seven predict a decrease in mean

330 net precipitation and three an increase. The bounds of the bootstrapped $95 \%$ confidence interval

331 on the ensemble mean are $-21.5 \%$ and $2.9 \%$. The sign of change for net precipitation thus remains

332 uncertain. To facilitate simulations, groundwater recharge variations of $+10 \%,-15 \%$ and $-30 \%$ of 
333 the calibrated values are used to study the sensitivity of peatland-aquifer interactions under

334 climate change. These percentages are a simplification of the complex multi-scenario possibilities

335 but are considered sufficiently representative to generate informative results. In the literature,

336 recharge variations due to climate change for humid areas are expected to differ significantly

337 depending on topography, geology and climate. The recharge variations used here are similar to

338 those reported in literature: -59 to $+15 \%$ in the Chateauguay watershed (Croteau et al., 2010),

$339+53 \%$ in the Grand River watershed of Ontario, Canada (Jyrkama and Sykes, 2007), +11 to $+25 \%$

340 in the Grand Forks aquifer of British Columbia, Canada (Scibek et al., 2007), -40 to $+31 \%$ for

341 various locations in Great Britain (Herrera-Pantoja and Hiscock, 2008; Jackson et al., 2011). In

342 the semi-arid region of the southern High Plains of Texas, USA, Ng et al. (2010) report climate

343 change induced groundwater recharge variations from $-75 \%$ to $+35 \%$.

345 3. RESULTS AND DISCUSSION

$346 \quad 3.1$ Model calibration, measured and simulated baseline conditions

347 The calibrated Ks in the groundwater model are within the interval of measured values

348 (Barrington et al., 1992; Fournier, 2008; Lavigne et al., 2010a), decreasing with depth as

349 observed with field measured data (Figure 5). The calibrated $\mathrm{K}$ in the peatland is high in the top

350 two layers of organic deposits and decreases rapidly below this depth. Below these layers $\mathrm{K}$ is set

351 to even lower values to represent gradually more humified and less permeable peat. The $\mathrm{K}_{\mathrm{h}} / \mathrm{K}_{\mathrm{v}}$

352 ratio in bedrock layers $1-9$ of zones 2 and 3 is set to 1000 and 100 respectively, to represent the

353 predominantly horizontal groundwater flow within the horizontal bedding planes. The $\mathrm{K}_{\mathrm{h}} / \mathrm{K}_{\mathrm{v}}$ ratio

354 layers 10-12 for zones 1, 2 and 3 are set to 100, and the deeper anisotropy for these zones is set to

355 10. In zone 4 , the $\mathrm{K}_{\mathrm{h}} / \mathrm{K}_{\mathrm{v}}$ ratio is 10 for all layers. The calibrated conductance for the River nodes

356 is $200 \mathrm{~m}^{2} \mathrm{~d}^{-1}$. This value provides the best estimates of river base flows. Calibrated conductance

357 for the drains is $500 \mathrm{~m}^{2} \mathrm{~d}^{-1}$.

358 
359 For the steady-state simulation, the maximum possible recharge was limited to the average annual

360 net precipitation for the 2007-2012 period $\left(400 \mathrm{~mm} \mathrm{y}^{-1}\right)$. The steady-state calibrated average

361 recharge for the entire domain is $113 \mathrm{~mm} \mathrm{y}^{-1}$, i.e. $28 \%$ of this average net precipitation. The

362 difference between net precipitation and recharge can be justified by the diversion of net

363 precipitation to streams and evacuated via surface routes (not simulated in this work). Spatially

364 calibrated recharge varies between 0 and $372 \mathrm{~mm} \mathrm{y}^{-1}$ (Table 2). The maximum value is attributed

365 to the peatland where little runoff occurs. The minimum recharge is calibrated on the northern

366 portion of the study area where compact till, silt and clay sediments are found. Although in reality

367 recharge is rarely nil, this value illustrates the very limited water volumes that can percolate

368 through these low permeability sediments. The calibrated recharge obtained in this study is lower

369 than the values of 162-180 and 227-240 $\mathrm{mm} \mathrm{y}^{-1}$ previously estimated by Croteau et al. (2010) and

370 Gagné (2010) respectively for the Allen and Outardes watersheds. This difference can be

371 attributed to the fact these authors calibrated recharge using soil reservoir models to reproduce

372 baseflow estimated from hydrograph separation. Because it is very difficult to distinguish

373 between recharge and subsurface runoff with hydrograph separation, this method can

374 overestimate actual recharge to the aquifer.

375

376 For the transient state simulations, Table 1 presents the seasonal values of recharge. Seasonal

377 recharge is lowest (almost zero) in summer and largest in the spring due to snowmelt. From 2007

378 to 2010 , the annual recharge varies from 98 to $172 \mathrm{~mm} \mathrm{y}^{-1}$. The storage coefficient was calibrated

379 to 0.004 for the bedrock in zone 2, and 0.001 in zones 3 and 4, typical values for fractured

380 bedrock (Anderson and Woessner, 1992).

381

382 Figures $6 \mathrm{a}$ and $\mathrm{b}$ show that the steady-state groundwater flow model simulates the available head

383 data without any systematic overestimation or underestimation of heads in any area of the study

384 domain (mean error $0.4 \mathrm{~m}$, mean absolute error $7.2 \mathrm{~m}$ and root mean squared error $9.3 \mathrm{~m}$ ). The 
385 simulated errors can be partially explained by the fractured and probably highly heterogeneous

386 bedrock aquifer, a condition not represented with the equivalent porous media model. The error

387 on the simulated heads could also arise from the inaccuracy of the SIH data, because it is

388 measured over several years, there are variable drilling depths, and the reference topography

389 (which itself is highly varied) is estimated, and from the inaccuracy in the elevation model.

390 Nevertheless, the calibrated model simulates the large head differences observed over this

391 headwater area relatively well.

392

393 Figure 7 illustrates measured and simulated heads from 2007 to 2010 for the peatland and three

394 wells located at the top of the hill, at mid-slope, and at the foot of the hill. The heads are plotted

395 relatively (i.e. elevation centered on 0) to remove any errors related to topographical inaccuracies.

396 The simulated groundwater levels compare reasonably with the observation data. For example,

397 the Nash-Sutcliffe efficiency coefficient (Nash and Sutcliffe, 1970), comparing the seasonal

398 bedrock observation well heads to the simulated heads, where $\mathrm{E}=1$ corresponds to a perfect

399 match, ranges from 0.983 to 0.998 for the illustrated wells and is similar for the additional

400 bedrock monitoring wells. For the peatland piezometers, the efficiency coefficients are similar

401 (e.g. 0.994 as illustrated in Figure 7). Errors in the transient state simulation are expected to be

402 caused in part by the porous media representation of the fractured bedrock aquifer and the

403 imprecision in storage coefficient calibration.

404

405 Table 1 shows that the magnitudes of seasonal baseflows are relatively well simulated for the

406 Allen and Outardes rivers, and for the Schulman stream. Model baseflows range from 0.08 to

$4070.20 \mathrm{~m}^{3} / \mathrm{s}$ for the Allen, 0.05 to $0.24 \mathrm{~m}^{3} / \mathrm{s}$ for the Outardes and 0.006 to $0.014 \mathrm{~m}^{3} / \mathrm{s}$ for the

408 Schulman. However, the simulated values generally vary less from year to year than the

409 Chapman estimated baseflows. This could be due to the modeling methodology in which bulk

410 seasonal recharge values are used on three month stress periods, rather than storm-specific 
411 precipitation and recharge extremes encountered in nature. Also, it must be remembered that the

412 Chapman estimated baseflows are only crude estimations of the aquifer contribution to the rivers.

413 Considering the simple representation of the groundwater contribution to rivers, these results are

414 considered satisfactory.

416 Fournier (2008) has estimated the groundwater flow contribution to the peatland using the Darcy

417 equation with bedrock-peatland head gradients and measured hydraulic conductivities. The same

418 technique was used here on a seasonal basis. The average seasonal hydraulic gradient between the

$4194.5 \mathrm{~m}$ bedrock piezometer located near the peatland and the closest peatland piezometer is used in

420 this calculation. During the 2007-2010 period, this hydraulic gradient was on average slightly

421 higher during the spring $(0.0032 \mathrm{~m} / \mathrm{m})$, a mid-value during the fall $(0.0031 \mathrm{~m} / \mathrm{m})$ and lowest

422 during the summer $(0.0029 \mathrm{~m} / \mathrm{m})$. It is assumed to be constant all along the $5580 \mathrm{~m}$ of the aquifer-

423 peatland North and South inflow lengths. The hydraulic conductivity corresponds to the average

424 between $4.5 \mathrm{~m}$ bedrock piezometer $\mathrm{K}\left(3.54 \times 10^{-5} \mathrm{~m} / \mathrm{s}\right)$ and the hydraulic conductivity of the

425 topmost $0.5 \mathrm{~m}$ of peat deposits $\left(1.84 \times 10^{-3} \mathrm{~m} / \mathrm{s}\right)$. The model simulates groundwater inflows to the

426 peatland (Table 1) similar to the Darcy flux values for the spring ( 0.0072 for the model vs. 0.0082

$427 \mathrm{~m}^{3} / \mathrm{s}$ for Darcy), but lower for the summer $\left(0.0037 \mathrm{vs} .0 .0076 \mathrm{~m}^{3} / \mathrm{s}\right)$ and fall $(0.0053 \mathrm{vs} .0 .0080$

$428 \mathrm{~m}^{3} / \mathrm{s}$ ) seasons. Although relatively small, this groundwater inflow to the peatland is nevertheless

429 important for the hydrological dynamics of the peatland, its ecosystem and habitat diversity. This

430 inflow provides sustained minerals, nutrients and water to maintain rich and diverse plant

431 communities identified in the minerotrophic transition zone (lagg ecotone; Pellerin et al. 2009).

432 The direction of groundwater flow (i.e. always from aquifer to peatland under current climate

433 conditions) is also correctly simulated. Because of the significantly higher hydraulic

434 conductivities in the upper peat layers, the model simulates groundwater movement through the

435 peatland mainly in the topmost $0.5 \mathrm{~m}$. Similar dominating superficial flow within the top layers of 436 a peatland has also been reported in other field studies (e.g. Devito et al., 1996). 
437 The model predicts groundwater outflow from the peatland in the direction of the Allen and

438 Outardes rivers, equivalent to 4 to $7 \%$ of the total baseflow to each river. Simulated flows from

439 the peatland to the two rivers are largest during the spring and fall seasons with a total out flow of

$440 \quad 0.0157$ and $0.0131 \mathrm{~m}^{3} / \mathrm{s}$ respectively for the two seasons. Outflows remains non-negligible (under

441 current conditions) throughout the year (minimum $0.0102 \mathrm{~m}^{3} / \mathrm{s}$ during the winter), with highest

442 contributing percentages in summer and winter when river baseflows are the lowest. Other studies

443 (e.g. Devito et al., 1997) have shown that baseflow from a headwater peatland can be interrupted

444 during the dry season in a low permeability headwater bedrock settings. Although the

445 groundwater flow model for Covey Hill does not provide detailed information on river baseflows,

446 the simulations show that the storage-release capacity of the peatland is important to support river

447 low flows. Similarly to other headwater peatlands, the Covey Hill peatland appears to play a

448 significant buffer role in a hydrological system where the soil and surface deposits offer little

449 storage potential to maintain river flows during the dry season.

451 Twelve percent of the recharge applied to the model domain is discharged from the aquifer to the

452 small streams which are represented by drains. This corresponds to a significant volume of water,

453 of a similar magnitude to the simulated baseflows of the Allen or the Outardes River. Thirty

454 percent of the recharge emerges in the Allen and Outardes rivers as well as in the Schulman

455 stream uptream from the gauging stations (see Figure 1). Twelve percent emerges in the two

456 rivers below their gauging stations where the rivers flow mostly on impervious sediments and

457 have little interaction with the aquifer.

458

459 During an average year, the total flow to the regional aquifer through the northern boundary is

460 equivalent to $52 \mathrm{~mm} \mathrm{y}^{-1}$. This inter-aquifer flow represents $46 \%$ of the average calibrated

461 recharge for the study domain. Covey Hill is a recharge zone but small streams and rivers

462 intercept a significant part of this recharge. The volume of water that actually reaches the regional 
463 aquifer is therefore much lower than what reaches the saturated zone. This is rarely taken into

464 consideration when evaluating regional recharge with 1D water budget methods. This proportion

465 of total recharge that reaches the regional aquifer as groundwater flow cannot be verified with

466 field measurements but appears reasonable given the other simulated flows. Comparatively, in a

467 nearby watershed in south-western Quebec, Nastev et al. (2006) found that discharge to

468 secondary streams comprised $37 \%$ of the water budget.

$470 \quad 3.2$ Simulated climate change scenarios

471 The recharge scenarios investigated in this study are considered a representative range of possible

472 recharge variations for a future climate. Although the 2007-2010 period during which detailed

473 transient hydrological data are available is outside the 1971-2000 reference period for the climate

474 change scenarios, the four recharge scenarios are simulated up to 2010 to facilitate comparison

475 with recent conditions.

477 Figure 8 illustrates variations in heads, river and stream flows, as well as subsurface outflow

478 through the northern boundary for each of the recharge scenarios relative to the spring 2010

479 baseline results. Trends are similar for data from other seasons and years. Recharge variations of

$480+10,-15$ and $-30 \%$ induce median head changes of $+1.1,-1.9$ and $-4.2 \mathrm{~m}$ respectively. This high

481 sensitivity of groundwater levels to recharge variations is probably a common trait of headwater

482 aquifers and is an argument in favor of management measures that would limit human-induced

483 recharge reductions or wetland drainage in headwater systems. Nevertheless, the headwater

484 system apparently has some resilience, buffering recharge variations to a limited extent.

485 Interestingly, removing the peatland (i.e. zone 1) from the model in steady state, and therefore

486 simulating a major perturbation scenario, produces a reduction in heads similar to a $15 \%$ decrease

487 in recharge (results not shown). The water holding capacity of the organic deposits therefore

488 contributes to some extent to maintain high groundwater levels near the top of the Covey Hill 
489 headwater system. In the absence of soils and surface deposits, the Blueberry, Gouffre and Forêt

490 Enchantée lakes certainly also contribute to the hydrological resilience of the system. Beyond a

491 certain level of recharge reduction, heads change more significantly (and this change is much

492 more variable in space), the largest changes being observed on the top of the hill. This agrees

493 with results from other studies (e.g. Lavigne et al., 2010b) which have shown that the highest

494 sensitivity of groundwater levels to pumping increases occurs in areas where potentiometric

495 heads are the highest.

496

497 Total contribution from the aquifer to the Allen and Outardes rivers, to the Schulman stream and 498 to all the small streams varies from $+14 \%$ to -22 and $-44 \%$ of the baseline for the $+10 \%,-15 \%$

499 and $-30 \%$ recharge scenarios respectively (Figure 8). In the model, the Allen and Outardes rivers

500 never become dry because they are represented using MODFLOW's River package. This is

501 probably realistic since inputs from the peatland and from a series of lakes along their courses

502 provide significant reservoirs to maintain flow throughout the year. The Schulman stream and the

503 smaller streams located on the northern face of the hill simulated with the Drain package can

504 become seasonally isolated from the aquifer due to low piezometric levels, which represents

505 drying. When recharge decreases, small streams and springs dry out. This drying of small streams

506 and springs could have an adverse effect on endangered salamanders species found on Covey Hill

507 (Larocque et al., 2006).

508

509 As recharge decreases, the proportion of the recharge flowing to the regional aquifer increases

510 only slightly for the $-15 \%$ and $-30 \%$ scenarios respectively. As less water is diverted to surface

511 routes, more (proportionately) can flow to the regional aquifer. This comes from the drying out of

512 small streams that otherwise drain groundwater towards surface streams and rivers. Conversely, a

$51310 \%$ increase in recharge drives more water to rivers and drains and less, percentage wise, to the

514 regional aquifer. 
515 During the 2007-2010 period, the peatland was constantly fed by the aquifer. Groundwater input

516 to the peatland increases with the $+10 \%$ recharge scenario, leading to an increase in heads and to

517 more water drained by the peatland outlets. When recharge decreases by $15 \%$, water flows from

518 the bedrock aquifer to the peatland on the southern portion and from the peatland to the aquifer

519 on its northern side (Figure 9). Outflows from the peatland are even higher for the $-30 \%$ recharge

520 scenario. Also, oxidation of peat and vegetation changes could also occur in response to reduced

521 groundwater inflow to the peatland. Extrapolating from a trend line for flow to the peatland from

522 the aquifer, a recharge decrease of $16.5 \%$ causes an annual net groundwater contribution to the

523 peatland of zero. Figure 10 shows that with the $-30 \%$ recharge scenario, flow reversals occur

524 during the summer, fall and winter seasons, and sometimes during the spring. Under these

525 conditions, the flow regime changes and more water flows out of the peatland than into it through

526 most of the year. This could induce water table drawdowns within the peatland that are beyond

527 the threshold of peatland vegetation resilience to groundwater level variations. Significant

528 vegetation changes could result from this situation with tree growth increase and further reduction

529 of the organic matter accumulation within the peatland. Frequent or long term changes of this

530 nature could impair the buffer function of the headwater peatland. Conversely, with higher

531 recharge some areas of the peatland would become totally flooded. This could significantly

532 impact its vegetation favouring for instance the spread of minerotrophic marshes and aquatic

533 plants (Swan and Gill, 1970; Asada et al., 2005).

535 It is noteworthy to underline the fact that detailed representation of recharge fluxes and changes

536 in the seasonal occurrence of recharge are not included in this study. This is especially true for

537 winter conditions. Under climate change, the RCM scenarios predict higher winter temperatures,

538 with a mean temperature change of $+3.1^{\circ} \mathrm{C}$, ranging from $+2.1^{\circ} \mathrm{C}$ to $+4.2^{\circ} \mathrm{C}$. This will lead to a

539 shorter period of below zero temperatures (10 to 14 days), more frequent recharge events during

540 the winter season, reduced snow accumulation and reduced spring recharge. The climate models 
541 indicate an increase in rainfall intensity with the $90^{\text {th }}$ percentile of the maximum daily

542 precipitation rising from 63.7 to $72.7 \mathrm{~mm}$. A detailed soil water budget model would have been

543 necessary along with monthly (or shorter) stress periods to illustrate in more details the impact of

544 increased winter recharge or rainfall intensity on local and regional groundwater flow.

545

546 For the two recharge reduction scenarios, the peatland groundwater contributing area is mostly

547 located at the southwest of the peatland and is reduced from $1.7 \mathrm{~km}^{2}$ to 1.2 and $1.1 \mathrm{~km}^{2}$

548 respectively. As mentioned above, the peatland watershed is relatively small and influenced only

549 by local groundwater flow. In this respect, the Covey Hill peatland is probably typical of

550 peatlands located in headwater systems where undulating topography limits the area contributing

551 to groundwater flow. This situation makes it particularly sensitive to hydrological changes in

552 rainfall and recharge.

553

554 4. CONCLUSION

555 This work provides insights into the hydrological functions of a headwater system and peatland in 556 regulating groundwater levels and river baseflows. Under current conditions, this work confirms

557 that the Covey Hill peatland is fed by the fractured bedrock aquifer year round and provides

558 continuous baseflow to its outlets. A peatland located in a headwater system where surface

559 deposits are scarce is expected to play an important role as a water reservoir, helping to regulate

560 the impacts of climate variability. A suite of Regional Climate Model scenarios have provided a

561 net precipitation variation range from $-30 \%$ to $+10 \%$ for the $2041-2070$ horizon. This range was

562 used to modify calibrated recharge values. Over the studied headwater system, recharge

563 reductions induce sharp declines in groundwater levels and drying streams. Recharge variations

564 of $+10,-15$ and $-30 \%$ induce median head changes of $+1.1,-1.9$ and $-4.2 \mathrm{~m}$ respectively. Close to

565 the peatland and within the organic deposits, hydraulic gradients change and the peatland

566 becomes perched above the aquifer during the summer, fall and winter. Although the climate 
567 change induced recharge scenarios tested in this work are hypothetical, results from this study

568 indicate that a headwater system can be highly vulnerable to recharge variations, both in terms of

569 heads and fluxes. Although the knowledge exists to link these trends to ecosystem changes, more

570 work is needed to establish specific thresholds and quantifiable ecological responses.

572 The MODFLOW model has proven to be adequate to simulate current groundwater flow

573 conditions in both steady and transient states in the Covey Hill headwater bedrock aquifer as well

574 as to simulate interactions between aquifer and peatland. This was achieved in spite of the

575 inevitable simplifications necessary to represent a regional aquifer, namely using an equivalent

576 porous media representation for the fractured bedrock and deriving recharge from net

577 precipitation values. Representing the peatland explicitly and not overly constraining it using, for

578 example, a constant head boundary condition, was necessary to study the peatland-aquifer

579 interactions. In further research based on additional field characterization, using a fully coupled

580 model could allow the simulation of runoff and infiltration as specific processes, as well as the

581 simulation of surface flow to rivers.

582

583 In this study, recharge variations were related to climate change. Other human-induced recharge

584 variations can result from increased urbanization or groundwater level decreases due to

585 groundwater abstraction to meet agricultural or urban needs. The hydrogeological impact of these

586 variations could be magnified if combined with climate change induced recharge reductions.

587 Under these conditions, current management practices might not be sufficient to ensure the long

588 term hydrological and ecosystem functions of a headwater system. More research is necessary to

589 include these considerations into management practices to develop adaptation strategies in the

590 anticipation of climate change and population growth.

591

592 


\section{ACKNOWLEDGEMENTS}

594 This project was funded by the climate change consortium Ouranos as part of the "Fonds vert" for

595 the implementation of the Quebec Government Action Plan 2006-2012 on climate change

596 (grant \#554007 - 107). The authors would like to thank Nature Conservancy of Canada for its

597 logistic contribution and for providing access to its property on Covey Hill. We also thank the

598 landowners for making their properties accessible for the study.

599

600 


\section{REFERENCES}

602 Ackerman MC, Blake JR, Booker DJ, Harding RJ, Reynard N, Mountford JO, Stratford CJ. 2009.

603 A simple framework for evaluating regional wetland ecohydrological response to climate 604 change with case studies from Great Britain. Ecohydrology doi:10.1002/eco.37.

605 Anderson MP, Woessner WW. 1992. Applied groundwater modeling: simulation of flow and 606 advective transport. Academic Press, Inc., San Diego, California, 381 p.

607 Asada T, Warner BG, Schiff SL. 2005. Effects of shallow flooding on vegetation and carbon 608 pools in boreal peatlands. Applied Vegetation Science 8:199-208.

609 Baird AJ, Morris PJ, Belyea LR. 2011. The DigiBog peatland development model 1: rationale, 610 conceptual model, and hydrological analysis. Ecohydrology doi:10.1002/eco.230.

611 Barrington S, Philion H, Bonin J. 1992. An evaluation of the water reserve potentials : the 612 ecological region of the Covey Hill « Gulf ». Agricultural Engineering report, Faculty of 613 Agriculture and Environmental Sciences, McGill University, McDonald campus, 53 p.

614 Beckwith CW, Baird AJ, Heatwaite AL. 2003a. Anisotropy and depth-related heterogeneity of 615 hydraulic conductivity in a bog peat. I: laboratory measurements. Hydrological Processes $616 \quad 17: 89-101$.

617 Beckwith CW, Baird AJ, Heatwaite AL. 2003b. Anisotropy and depth-related heterogeneity of 618 hydraulic conductivity in a bog peat. II: modeling the effects on groundwater flow. 619 Hydrological Processes 17:103-113.

620 Belyea LR, Malmer N. 2004. Carbon sequestration in peatlands: patterns and mechanisms of 621 response to climate change. Global Change Biology 10:1043-1052.

622 Brassard P, Waddington MJ, Hill AR, Roulet NT. 2000. Modelling groundwater-surface water 623 mixing in a headwater wetland: implication for hydrograph separation. Hydrological 624 Processes 14:2697-2710.

625 Calmé S, Desrochers A, Savard, JPL. 2002. Regional significance of peatlands for avifaunal 626 diversity in southern Quebec. Biological Conservation 107:273-281. 
627 Chapman, T. 1999. A comparison of algorithms for stream flow recession and baseflow

628 separation. Hydrological Processes 13:01-714.

629 Cook PG. 2003. A guide to regional groundwater flow in fractured rock aquifers. CSIRO Land 630 and water, Glen Osmond, SA, Australia, 115 p.

631 Croteau A, Nastev M, Lefebvre R. 2010. Groundwater recharge assessment in the Châteauguay

632 River watershed. Canadian Water Resourources Journal 35(4):451-468.

633 Devito KJ, Waddington MJ, Branfireun BA. 1997. Flow reversals in peatlands influenced by

634 local groundwater systems. Hydrological Processes 11:103-110.

635 Devito KJ, Hill AR, Roulet N. 1996. Groundwater-surface water interactions in headwater

636 forested wetlands of the Canadian Shield. Journal of Hydrology 181:127-147.

637 Devito KJ. 1995. Sulphate mass balances in headwater wetlands of the Canadian Shield:

638 influence of catchment hydrogeology. Canadian Journal of Fisheries and Aquatic Science

$639 \quad 52: 1750-1760$.

640 Ducks Unlimited Canada. 2006. Plan de conservation des milieux humides et de leurs terres

641 hautes adjacentes de la région administrative du Centre-du-Québec,

$642 \quad$ [http://www.canardsquebec.ca], 55 p.

643 Environment Canada. 2010. Moyenne climatique de la station Hemmingford Four winds Québec,

644 1961-2009.http://www.climate.weatheroffice.ec.gc.ca/climateData/dailydata.

645 Fournier V. 2008. Hydrologie de la tourbière du mont Covey Hill et implications pour la

646 conservation. M.Sc. thesis, Université du Québec à Montréal, 84 p.

647 Franzi D, Rayburn JA, Yansa CH, Knuepfer PLK. 2002. Late glacial water bodies in the

648 Champlain and Hudson lowlands, New York. In: New York State Geological

649 Association/New England Intercollegiate Geological Conference Joint Annual Meeting

$650 \quad$ Guidebook, pp. A5 1-23.

651 Gagné S. 2010. Contribution de l'eau souterraine aux cours d'eau et estimation de la recharge sur 652 le mont Covey Hill. M.Sc. Thesis Université du Québec à Montréal, 87 p. 
653 Globensky Y. 1986. Géologie de la région de Saint-Chrysostome et de Lachine (sud). Ministère 654 de l'énergie et des ressources.

655 Greyson R, Holdon J, Rose R. 2010. Long-term change in storm hydrographs in response to 656 peatland vegetation change. Journal of Hydrology 389:336-343.

657 Harbaugh AW. 2005. MODFLOW-2005, the U.S. Geological Survey modular ground-water 658 model -- the Ground-Water Flow Process: U.S. Geological Survey Techniques and Methods 659 6-A16, variously p. http://pubs.usgs.gov/tm/2005/tm6A16/ .

660 Herrera-Pantoja M, Hiscock KM, Boar RR. 2011. The potential impact of climate change on 661 groundwater-fed wetlands in eastern England. Ecohydrology doi:10.1002/eco.231.

662 Herrera-Pantoja M, Hiscock KM. 2008. The effects of climate change on potential groundwater 663 recharge in Great Britain. Hydrological Processes 22:73-86.

664 IPCC. 2000. Special report on emissions scenarios (SRES): A special report of working group III 665 of the intergovernmental panel on climate change. Cambridge University Press, Cambridge, $666 \quad$ UK.

667 Jackson CR, Meister R, Prudhomme C. 2011. Modelling the effects of climate change and its 668 uncertainty on UK Chalk groundwater resources from an ensemble of global climate model 669 projections. Journal of Hydrology 399:12-28.

670 Jyrkama MI, Sykes JF. 2007. The impact of climate change on spatially varying groundwater 671 recharge in the Grand River watershed (Ontario). Journal o Hydrology 338:237-250

672 Kosugi K, Katsura S, Katsuyama M, Mizuyama T. 2006. Water flow processes in weathered 673 granitic bedrock and their effects on runoff generation in a small headwater catchment. Water 674 Resources Resesarch, 42, W02414, doi:10.1029/2005WR004275.

675 Lapen DR, Price JS, Gilbert R. 2005. Modelling two-dimensional steady-state groundwater flow 676 and flow sensitivity to boundary condition in blanket peat complexes. Hydrological

677 Processes 19:371-386. 
678 Larocque M, Leroux G, Madramootoo C, Lapointe FJ, Pellerin S., Bonin J. 2006. Mise en place

679 d'un laboratoires National sur le mont Covey Hill (Québec, Canada). VertigO 7 (1):1-11.

680 Lasalle P. 1981. Géologie des sédiments meubles de la région de St-Jean-Lachine. Ministère de

681 l'Énergie et des Ressources du Québec, Direction générale de l'exploration géologique et

682 minérale, DPV. 780.

683 Lavigne MA, Nastev M, Lefebvre R. 2010a. Numerical simulation of groundwater flow in the

684 Châteauguay River aquifers. Canadian Water Resources Journal 35(4):469-486.

685 Lavigne MA, Nastev M, Lefebvre R, Croteau A. 2010b. Regional sustainability of the

686 Châteauguay River aquifers. Candian Water Resources Journal 35(4):487-502.

687 MDDEFP (Ministère du Développement durable, de l'Environnement, de la Faune et des Parcs -

688 Québec). 2010. www.mddep.gouv.qc.ca/eau/souterraines/sih/index.htm.

689 Mearns LO, Arritt S, Biner M, Bukovsky S, Sain S, Caya D, Correia Jr J, Flory D, Gutowski W,

690 Takle ES, Jones R, Leung R, Moufouma-Okia W, McDaniel L, Nunes AMB, Qian Y, Roads

691 J, Sloan L, Snyder M. 2012. The North American Regional Climate Change Assessment

692 Program overview of phase I results. Bulletin of the American Meteorological Society 93:

$693 \quad 1337-1362$.

694 Moore PD. 2002. The future of cool temperate bogs. Environmental Conservation 29:3-20.

695 Morton FI. 1983. Operational estimates of areal evapotranspiration and their significance to the

696 science and practice of hydrology. Journal of Hydrology 66 (1-4):1-76.

697 Mpelasoka FS, Chiew FHS. 2009. Influence of rainfall scenario construction methods on runoff

698 projections. Journal of Hydrometerology 10:1168-1183.

699 MRNF (Ministère des Ressources naturelles - Québec). 2007. Modèle d'élévation numérique

$700 \quad(10 \mathrm{~m})$ de la région de St-Jean Chrysostome (1 : 20 000), 31H04-0101. Base de données

701 topographiques du Québec, Québec, Canada. 
702 Music B, Caya D. 2007. Evaluation of the hydrological cycle over the Mississippi River Basin as

703 simulated by the Canadian Regional Climate Model (CRCM). Journal of Hydrometerology

$704 \quad 8: 969-988$.

705 Nash JE, Sutcliffe J V. 1970. River flow forecasting through conceptual models part I - A

706 discussion of principles. Journal of Hydrology 10(3):282-290.

707 Nastev M, Morin R, Godin R, Rouleau A. 2008. Developing conceptual hydrological model for

708 Potsdam sandstones in southwestern Quebec, Canada. Hydrogeology Journal 16:373-388.

709 Nastev M, Lefebvre R, Rivera A, Martel R. 2006. Quantitative assessment of regional rock

710 aquifers, south-western Quebec, Canada. Water Resources Management 20:1-18.

711 Ng, G-H C, McLaughlin D, Entekhab, D, Scanlon BR. 2010. Probabilistic analysis of the effects

712 of climate change on groundwater recharge. Water Resources Research 46 W07502,

713 doi:10.1029/2009WR007904.

714 Oudin L, Hervieu F, Michel C, Perrin C, Andreassian V, Anctil F, Loumagne C. 2005. Which

715 potential evapotranspiration input for a lumped rainfall-runoff model? Part 2-Towards a

716 simple and efficient potential evapotranspiration model for rainfall-runoff modelling. Journal

717 of Hydrology 303:290-306.

718 Parent M, Occhietti S. 1988. Late wisconsinian deglaciation and Champlain Sea invasion in the

719 St. Lawrence valley, Québec. Géographie physique et Quaternaire 42 :215-246

720 Pellerin S, Larocque M, Lavoie M, 2007. Rôle hydrologique et écologique régional de la

721 tourbière de Covey Hill. Report presented to the EJLB Foundation, $63 \mathrm{p}$.

722 Pellerin S, Lagneau LA, Lavoie M, Larocque M. 2009. Environmental factors explaining the

723 vegetation patterns in a temperate peatland. C.R. Biologies 332:720-731.

724 Poulin M, Rochefort L, Pellerin S, Thibault J. 2004. Threats and protection for peatlands in

725 Eastern Canada. Geocarrefour 79:331-344. 
726 Reeve AS, Warzocha J, Glaser PH, Siegel DI. 2001. Regional ground-water flow modeling of the

727 Glacial Lake Agassiz Peatlands, Minnesota. Journal of Hydrology 243:91-100.

728 Rosa E, Larocque M, Pellerin S, Gagné S, Fournier B. 2008. Determining the number of manual

729 measurements required to improve peat thickness estimations by ground penetrating radar.

$730 \quad$ Earth Surface Processes and Landforms doi:10.1002/esp.1741.

731 Rosa E, Larocque M. 2008. Investigating peat hydrological properties using field and laboratory

732 methods: application to the Lanoraie peatland complex (Southern Québec, Canada).

733 Hydrological Processes 22:1866-1875.

734 Salinas MJ, Blanca G, Romero AT. 2000. Riparian vegetation and water chemistry in a basin

735 under semiarid mediterranean climate, Andarax River, Spain. Environmental Management

736 26(5):539-552.

737 Scibek J, Allen D, Cannon AJ, Whitfield PH. 2007. Groundwater-surface water interaction under

738 scenarios of climate change using a high-resolution transient groundwater model. Journal of

739 Hydrology 133:165-181.

740 Strack M, Waddington MJ, Tuittila ES. 2004. Effect of water table drawdown on northern

741 peatland methane dynamics: Implications for climate change. Global Biochem. Cy. 18:4003-

7424010.

743 Swan JMA, Gill AM. 1970. The origins, spread, and consolidation of a floating bog in Harvard

744 Pond, Petersham, Massachusetts. Ecology 51:829-840.

745 Tarnocai, C. 2006. The effect of climate change on carbon in Canadian peatlands. Global

$746 \quad$ Planetary Change 53(4):222-232.

747 Tremblay T, Nastev M, Lamothe M. 2010. Grid-based hydrostratigraphic 3D modelling of the

748 Quaternary sequence in the Châteauguay River watershed, Quebec. Canadian Water

749 Resources Journal 35(4):377-398.

750 Waddington JM, Quinton. WL, Price JS, Lafleur PM. 2009. Advances in Canadian peatland

751 hydrology, 2003-2007. Canadian Water Resources Journal 34(2):139-148.

http://mc.manuscriptcentral.com/hyp 
2

3

4

5

6

7

8

9

10

11

12

13

14

15

16

17

18

19

20

21

22

23

24

25

26

27

28

29

30

31

32

33

34

35

36

37

38

39

40

41

42

43

44

45

46

47

48

49

50

51

52

53

54

55

56

57

58

59

60

752 Whittington PN, Price JS. 2006. The effects of water table draw-down (as a surrogate for climate

753 change) on the hydrology of a fen peatland, Canada. Hydrological Processes 20:3589-3600.

754 Winter TC. 2000. The vulnerability of wetlands to climate change: a hydrologic landscape

755 perspective. Journal of the American Water Resources Association 36(2):305-311.

756 Winter TC. 2007. The role of ground water in generating streamflow in headwater areas and in

757 maintaining base flow. Journal of the American Water Resources Association 43(1):15-25.

758

http://mc.manuscipiptcentral.com/hyp 
759 Table 1. Seasonal net precipitation, recharge, baseflows (for the gauging station locations

760 shown in Figure 1 estimated with Champan, 1999, and simulated) and aquifer-peatland

761 exchanged fluxes (estimated with Darcy and simulated) for the 2007-2010 period

\begin{tabular}{|c|c|c|c|c|}
\hline & Spring & Summer & Fall & Winter \\
\hline Net precipitation (mm) & $\begin{array}{l}0-132 * \\
(79)^{* *}\end{array}$ & $\begin{array}{l}-66-36 \\
(-31)\end{array}$ & $\begin{array}{c}102-227 \\
(150)\end{array}$ & $\begin{array}{l}133-285 \\
(213)\end{array}$ \\
\hline $\begin{array}{l}\text { Calibrated recharge for } \\
\text { transient state simulation } \\
(\mathrm{mm})\end{array}$ & $\begin{array}{c}40-119 \\
(87)\end{array}$ & $\begin{array}{c}0-11 \\
(3)\end{array}$ & $\begin{array}{c}31-69 \\
(46)\end{array}$ & $\begin{array}{l}0-0 * * * \\
(0)\end{array}$ \\
\hline \multicolumn{5}{|l|}{ Chapman baseflow $\left(\mathrm{m}^{3} / \mathrm{s}\right)$} \\
\hline - Allen River & $\begin{array}{l}0.18-0.40 \\
\quad(0.26)\end{array}$ & $\begin{array}{l}0.05-0.12 \\
\quad(0.09)\end{array}$ & $\begin{array}{l}0.07-0.17 \\
\quad(0.12)\end{array}$ & n.a. \\
\hline - Outardes River & $\begin{array}{l}0.15-0.40 \\
(0.27)\end{array}$ & $\begin{array}{l}0.02-0.15 \\
(0.07)\end{array}$ & $\begin{array}{c}0.02-0.18 \\
(0.09)\end{array}$ & n.a. \\
\hline - Schulman stream & $\begin{array}{l}0.018-0.024 \\
(0.021)\end{array}$ & $\begin{array}{l}0.002-0.004 \\
\quad(0.003)\end{array}$ & $\begin{array}{l}0.001-0.002 \\
\quad(0.002)\end{array}$ & n.a. \\
\hline \multicolumn{5}{|l|}{ Simulated baseflow $\left(\mathrm{m}^{3} / \mathrm{s}\right)$} \\
\hline - Allen River & $\begin{array}{l}0.12-0.20 \\
\quad(0.16)\end{array}$ & $\begin{array}{l}0.09-0.10 \\
(0.10)\end{array}$ & $\begin{array}{l}0.11-0.15 \\
\quad(0.13)\end{array}$ & $\begin{array}{l}0.08-0.09 \\
(0.09)\end{array}$ \\
\hline - Outardes River & $\begin{array}{l}0.11-0.24 \\
(0.19)\end{array}$ & $\begin{array}{l}0.06-0.07 \\
(0.07)\end{array}$ & $\begin{array}{l}0.10-0.16 \\
(0.12)\end{array}$ & $\begin{array}{l}0.05-0.06 \\
(0.06)\end{array}$ \\
\hline - Schulman stream & $\begin{array}{l}0.010-0.022 \\
\quad(0.017)\end{array}$ & $\begin{array}{l}0.007-0.008 \\
(0.007)\end{array}$ & $\begin{array}{l}0.009-0.014 \\
(0.011)\end{array}$ & $\begin{array}{l}0.006-0.007 \\
\quad(0.007)\end{array}$ \\
\hline $\begin{array}{l}\text { Darcy aquifer-peatland flow } \\
\left(\mathrm{m}^{3} / \mathrm{s}\right)\end{array}$ & $(0.0082)$ & $(0.0076)$ & $(0.0080)$ & n.a. \\
\hline $\begin{array}{l}\text { Simulated aquifer-peatland } \\
\text { flow }\left(\mathrm{m}^{3} / \mathrm{s}\right)\end{array}$ & $\begin{array}{l}0.0047-0.0090 \\
\quad(0.0072)\end{array}$ & $\begin{array}{l}0.0034-0.0041 \\
\quad(0.0037)\end{array}$ & $\begin{array}{l}0.0046-0.0065 \\
(0.0053)\end{array}$ & $\begin{array}{l}0.0029-0.0034 \\
\quad(0.0032)\end{array}$ \\
\hline
\end{tabular}

762

*: minimum and maximum values

$763 * *$ : average value

$764 * * *$ : winter recharge is applied in the spring (i.e. when snow melts)

765 n.a.: data not available 
768 Table 2. Calibrated annual recharge rates for each recharge zone under current conditions

\begin{tabular}{clc}
\hline Zone & Type of surface deposits & Calibrated recharge $\mathbf{~ m m ~}^{\mathbf{- 1}} \mathbf{)}$ \\
\hline $\mathbf{1}$ & Peatland & 372 \\
$\mathbf{2}$ & Till over Flatrock & 117 \\
$\mathbf{3}$ & Till & 219 \\
$\mathbf{4}$ & Fractured bedrock & 329 \\
$\mathbf{5}$ & Shallow till over fractured & 303 \\
& bedrock & 183 \\
$\mathbf{6}$ & Fractured bedrock & 128 \\
$\mathbf{7}$ & Post-glacial littoral sediments & 0 \\
$\mathbf{8}$ & Compact till, silt and clay & \\
& sediments & \\
\hline
\end{tabular}


771 Table 3. RCM runs considered in this study (see Mearns et al. 2012 for model acronym

772 details)

\begin{tabular}{ccccc}
\hline RCM & GCM & Member & Domain & $\begin{array}{c}\text { Emissions } \\
\text { scenario }\end{array}$ \\
\hline CRCM4.2.3 & CGCM3 & 5 & AMNO & A2 \\
CRCM4.2.3 & CGCM3 & 2 & AMNO & A2 \\
CRCM4.2.3 & ECHAM5 & 1 & AMNO & A2 \\
CRCM4.2.3 & ECHAM5 & 2 & AMNO & A2 \\
CRCM4.2.3 & Arpège UnifS2 & -- & AMNO & A1B \\
CRCM4.2.0 & CGCM3 & 4 & AMNO. & A2 \\
HRM3 & HADCM3 & -- & QC & A2 \\
CRCM & CCSM & -- & N. Amer. & A2 \\
ECP2 & GFDL & -- & N. Amer. & A2 \\
RCM3 & CGCM3 & -- & N. Amer. & A2 \\
\hline
\end{tabular}

773

774

775 
a)
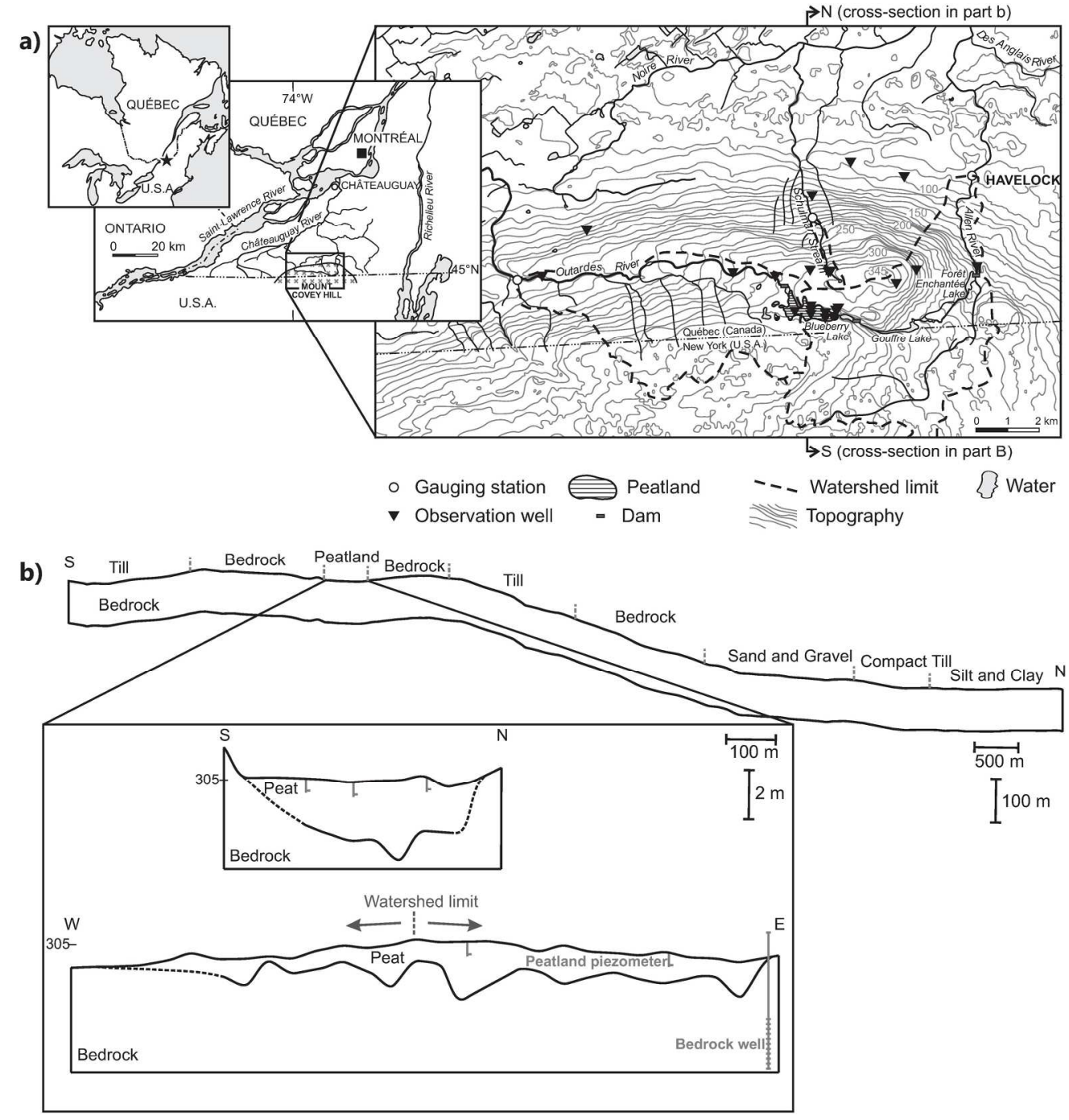

Figure 1. a) location of the Covey Hill Natural Laboratory and b) regional and peatland cross-sections. Note that SIH wells are not represented in this figure. The delineated "watershed limits" correspond to the gauging station watersheds. $188 \times 199 \mathrm{~mm}(300 \times 300$ DPI) 


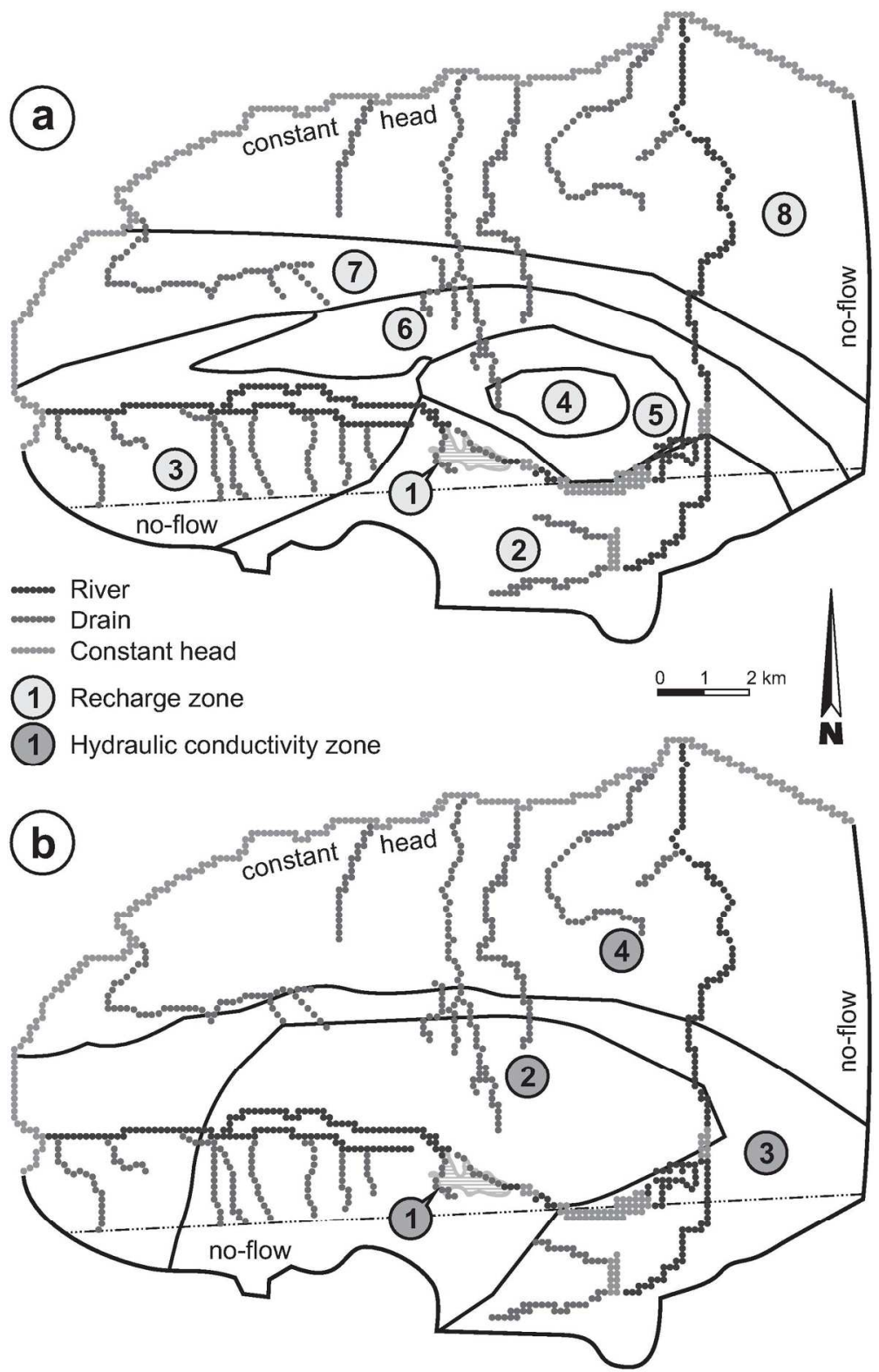

The conceptual groundwater flow model of Covey Hill: a) recharge zones and b) hydraulic conductivity zones $130 \times 205 \mathrm{~mm}(300 \times 300 \mathrm{DPI})$ 


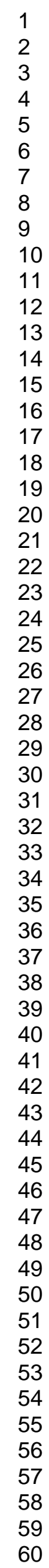

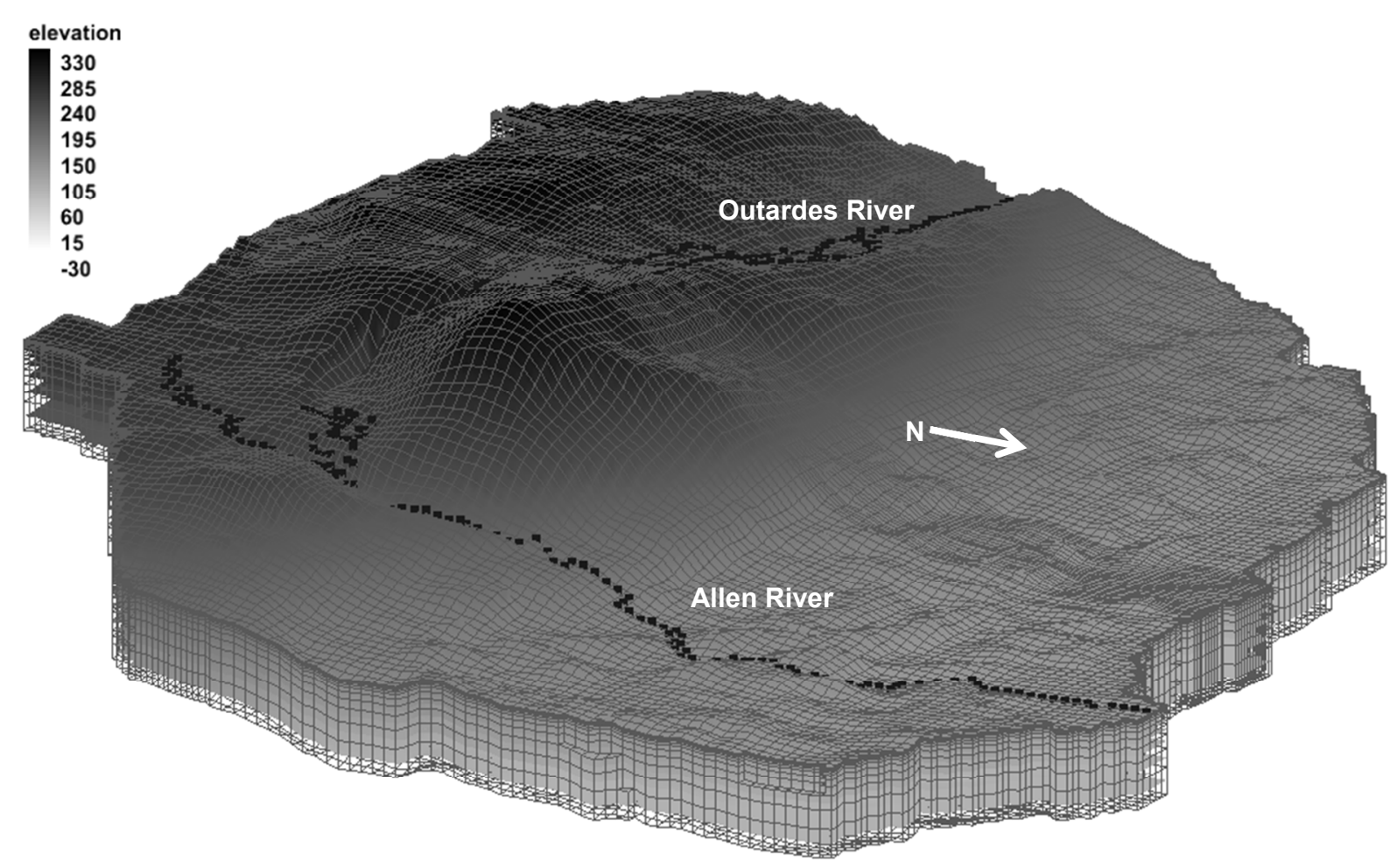

http://mc.manuscriptcentral.com/hyp 


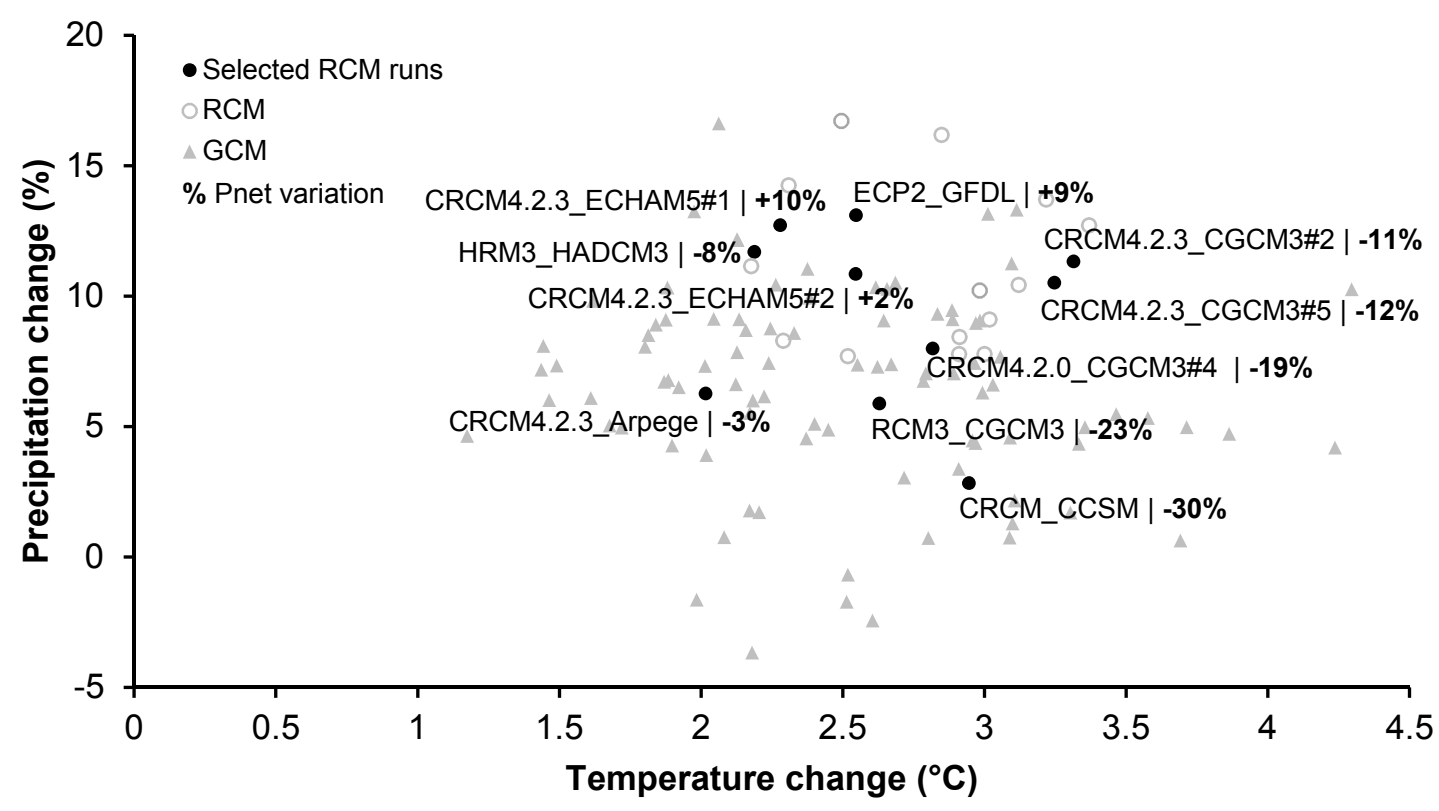

http://mc.manuscriptcentral.com/hyp 
Page 39 of 44

Hydrological Processes

1
2
3
4
5
6
7
8
9
10
11
12
13
14
15
16
17
18
19
20
21
22
23
24
25
26
27
28
29
30
31
32
33
34
35
36
37
38
39
40
41
42
43
44
45
46
47
48
49
50
51
52
53
54
55
56
57
58
59
60

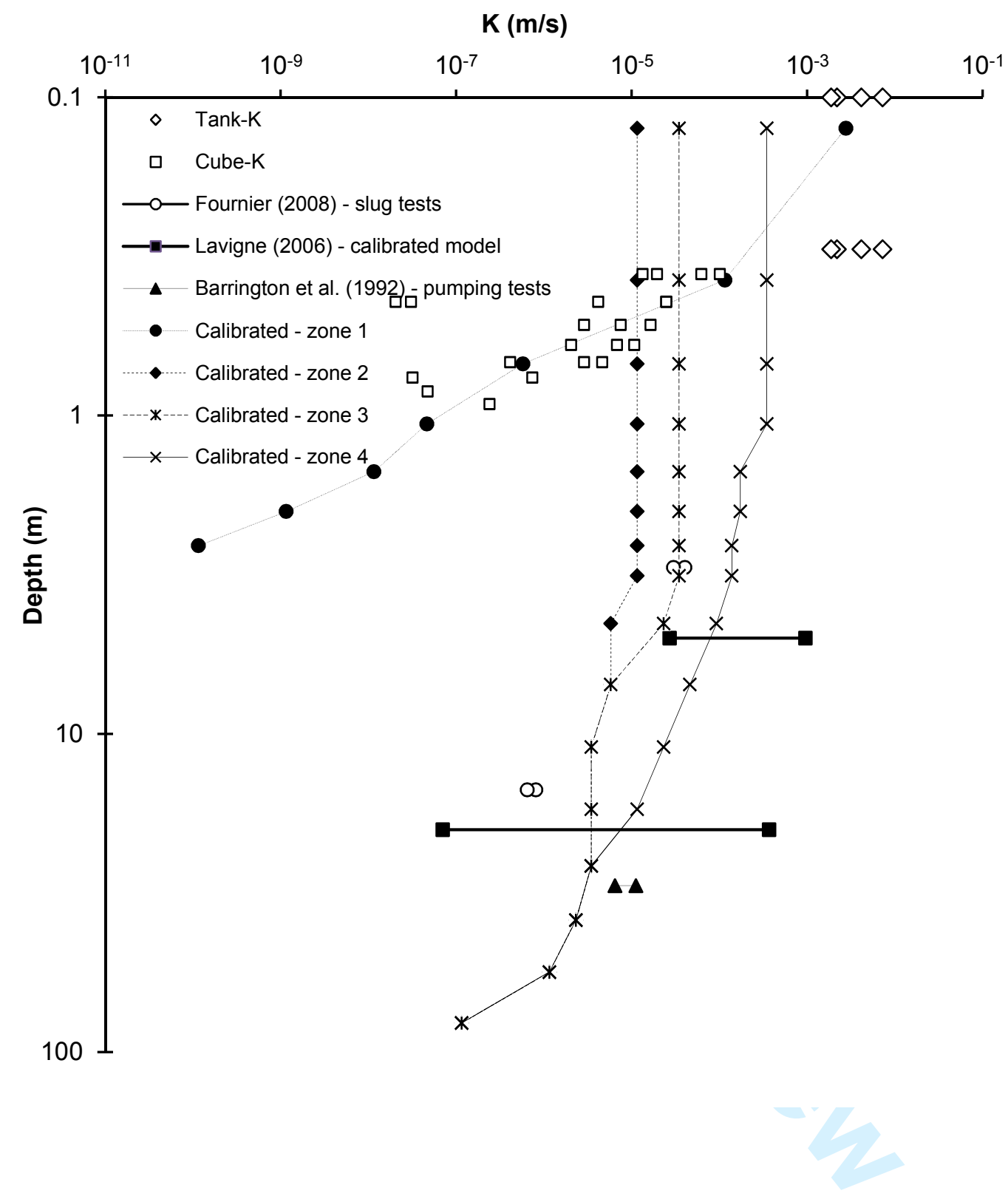

http://mc.manuscriptcentral.com/hyp 


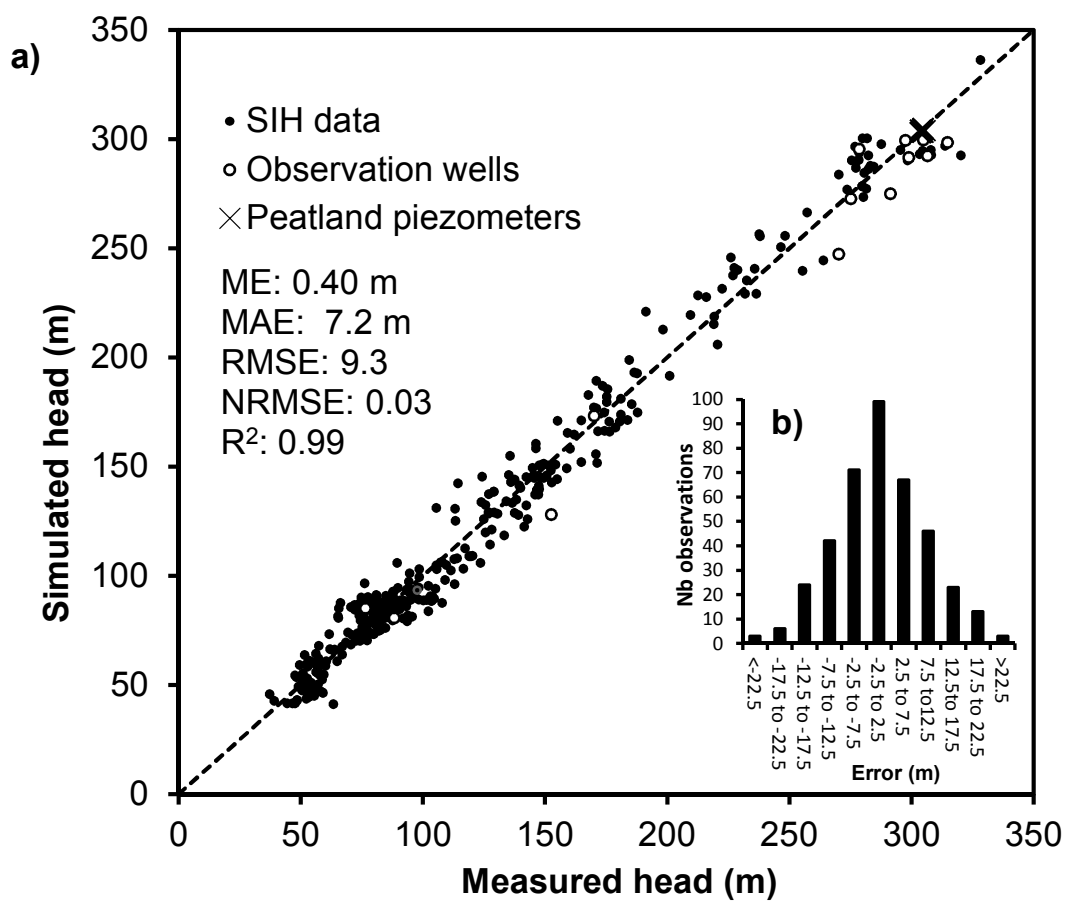

1
2
3
4
5
6
7
8
9
10
11
12
13
14
15
16
17
18
19
20
21
22
23
24
25
26
27
28
29
30
31
32
33
34
35
36
37
38
39
40
41
42
43
44
45
46
47
48
49
50
51
52
53
54
55
56
57
58
59
60 

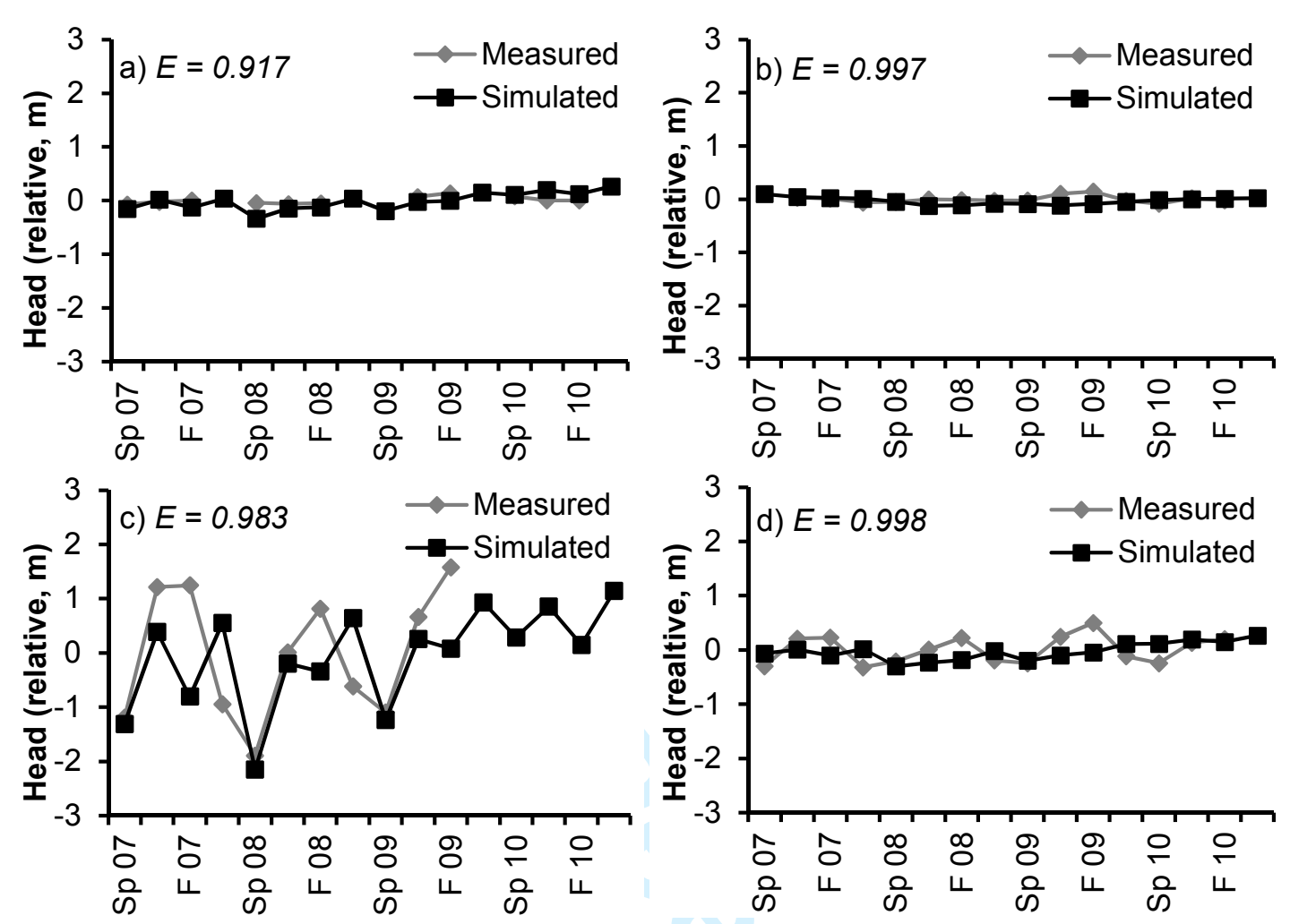


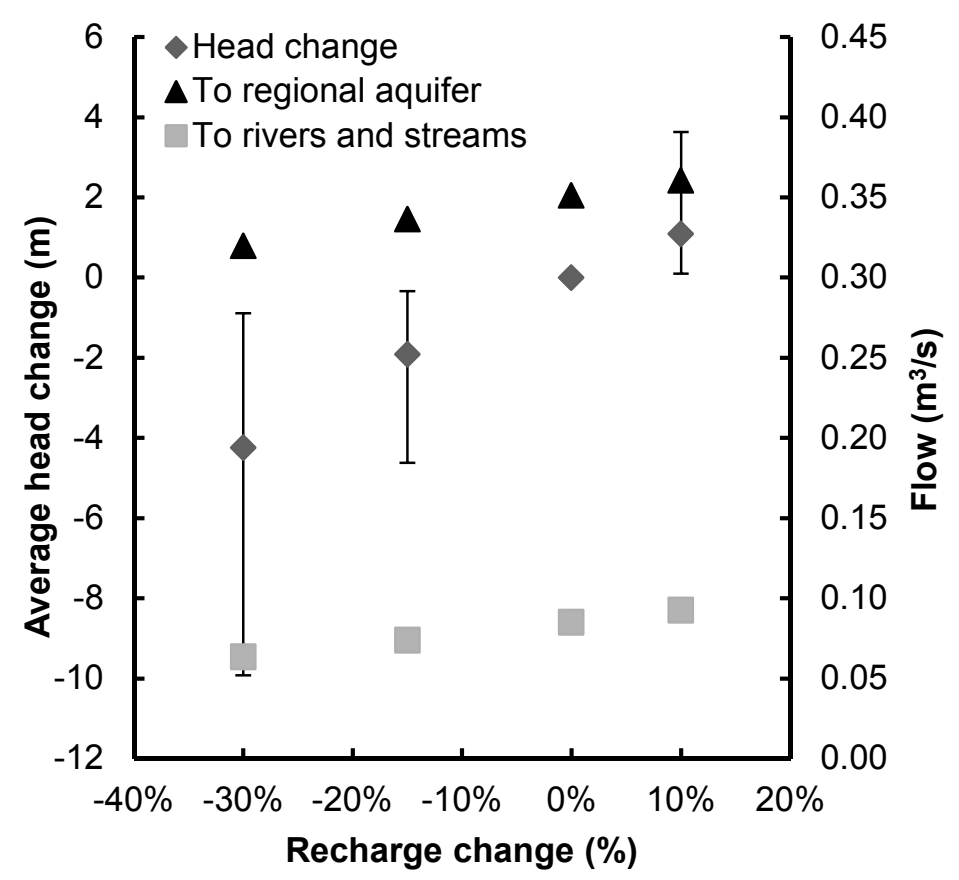

http://mc.manuscriptcentral.com/hyp 

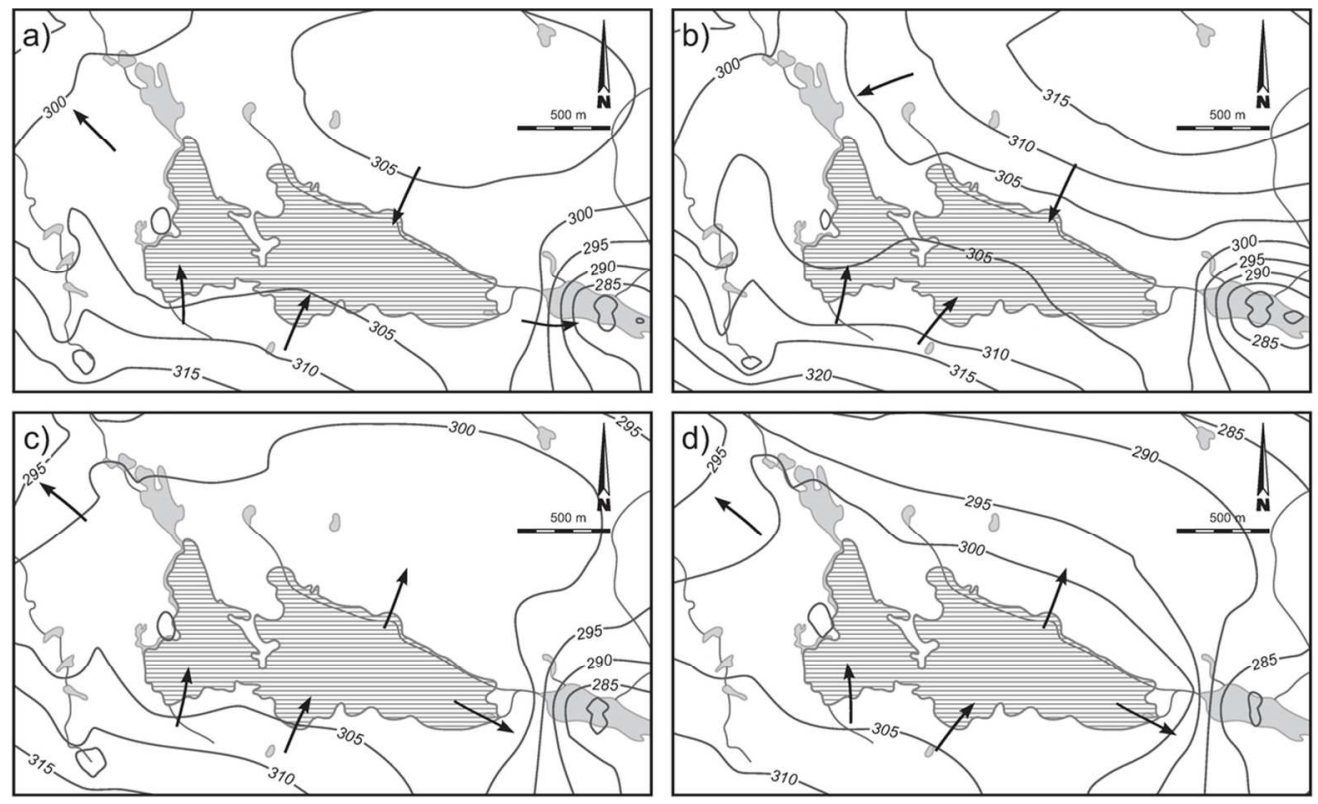

Simulated flow directions in the peatland contribution area a) for spring 2010 , and for the recharge scenarios b) $10 \%$ increase, c) $15 \%$ decrease and d) $30 \%$ decrease $103 \times 62 \mathrm{~mm}(300 \times 300 \mathrm{DPI})$ 


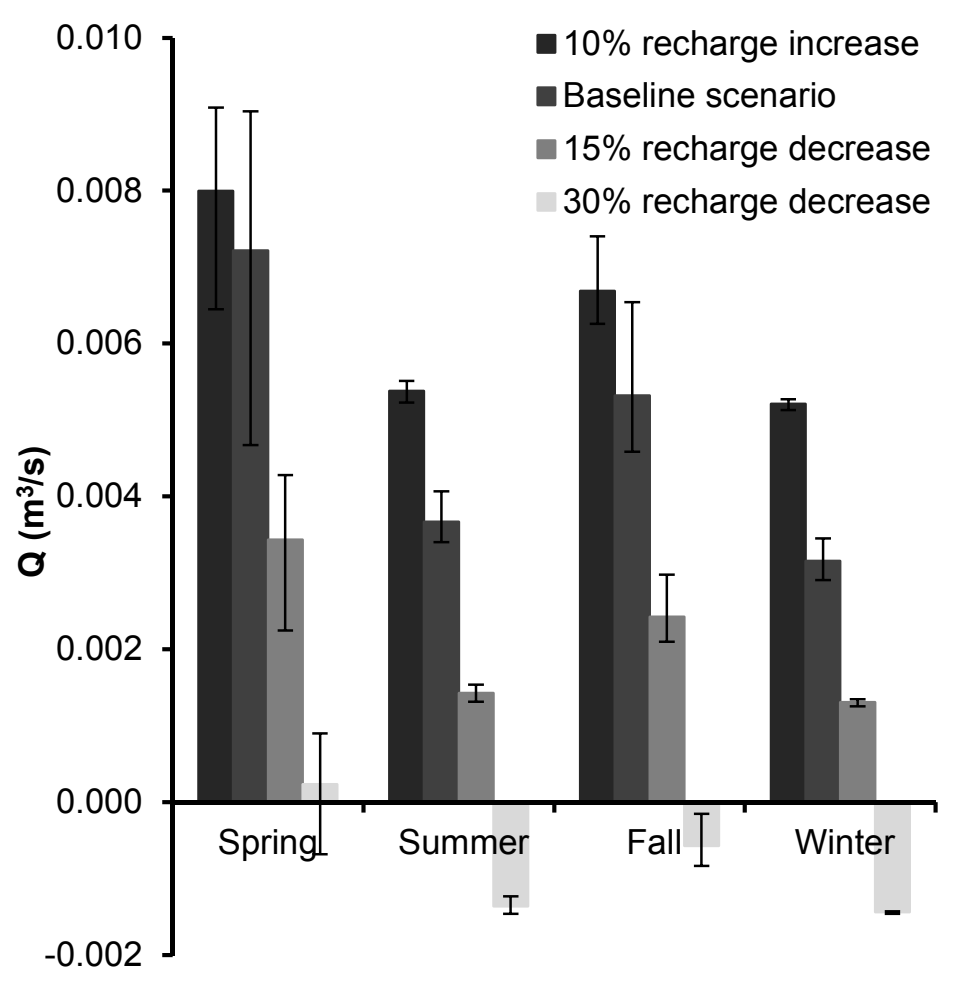

